TAPROBANICA, ISSN 1800-427X. April, 2013. Vol. 05, No. 01: pp. 77-80.

(C) Taprobanica Private Limited, 146, Kendalanda, Homagama, Sri Lanka.

www.taprobanica.org

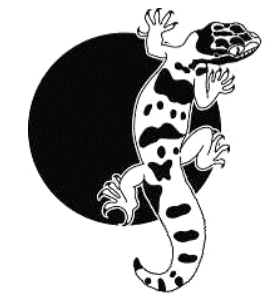

\section{The confirmed record of Oligodon albocinctus (Cantor, 1839) from Bangladesh}

Oligodon albocinctus (Cantor, 1839) has been recorded in Assam, Sikkim and Arunachal Pradesh of India, Nepal, Myanmar and China (Das et al., 2009). Khan $(1982,2010)$ included this species as common and found in the north and east of Bangladesh. However Sarker \& Sarker $(1985,1988)$ did not include this species in their checklists of the snakes of Bangladesh. The IUCN local red list (IUCN Bangladesh, 2003) included this species as data deficient. Khan (2008) stated that this species was expected to be found in Bangladesh. Kabir et al. (2009) included this species in the Encyclopedia of Flora and Fauna of Bangladesh based on IUCN Bangladesh (2003). However none of the previous reports were based on a specimen or photographic evidence, hence this is the first confirmed record of Oligodon albocinctus from Chunati Wildlife Sanctuary, Bangladesh, with a specimen and photographs.

We conducted a survey as a part of the biodiversity monitoring from 25 July 2012 to 30 July 2012 in Chunati Wildlife Sanctuary, Bangladesh. Surveys were conducted during the day and night to search for herpetofauna. An adult female specimen of Oligodon albocinctus (SVL $70 \mathrm{~cm}$ ) (Fig. 1) was collected on 30 July 2012 at about 09:30 hr. from Jaldi Range ( $\left.21^{\circ} 59.408 \mathrm{~N}, 91^{\circ} 58.954 \mathrm{E}\right)$ of Chunati Wildlife Sanctuary, Chittagong District. After overnight heavy rain, on a cloudy morning, the snake came out from the bushes and headed to water streams. It was photographed and then preserved in $70 \%$ ethanol. The specimen was deposited in the Wildlife Museum of the Department of Zoology, Jahangirnagar University, Bangladesh under the catalogue number JUHG 00332 (Fig. 2). The photograph was deposited in the Raffles Museum of
Biodiversity Research, Singapore under the catalogue number ZRC (IMG) 2.173. Morphometric and meristic data were taken according to Neang et al. (2012) measurements and scale counts were taken under a $75 \mathrm{~mm}$ magnifying lenses using a digital caliper to the nearest $0.1 \mathrm{~mm}$. Measurements: SVL (snoutvent length), from the tip of the snout to the vent; HL (head length), from the tip of the snout to the posterior margin of the mandible; HD (head depth), vertical height between upper and ventral surfaces of head measured at HW; IO (interorbital distance), shortest distance between outer margins of supraoculars; ED (eye diameter), horizontal diameter of eye; SN (snout length), distance between the tip of the snout and anterior edge of eye; EN (eye to nostril), distance between anterior margin of eye and posterior margin of nostril; IN (internostril distance), horizontal distance between nostrils. Scale counts: DOR, number of scale rows at one head length behind the head, at midbody and at one head length prior to the vent; VEN (ventral scales), number of scales from the one scale (excluding pre-ventral) posterior to gulars to the vent excluding anal plate; ANL (anal plate), number of terminal scales immediately anterior to vent; SUB (subcaudal scales), number of paired subcaudal scales excluding the terminal scute; SUP (supralabials), number of scales on upper lip; INF (infralabials), number of scales on lower lip; MAX (maxillary teeth); TEMP (temporal), number of scales on the side of the head between the parietal scales and the supralabial scales; BB (body bands), number of crossbands across the back and down to the sides but not encircling the body; BT (bands on tail), number of cross-bands on the tail; SCB (number of scales in a longitudinal row covered by each band). Comparison with other similar species was based on Neang et al. (2012), David et al. (2008), Das (2002), Smith (1943), Whitaker \& Captain (2004) and Kabir et al. (2009). 


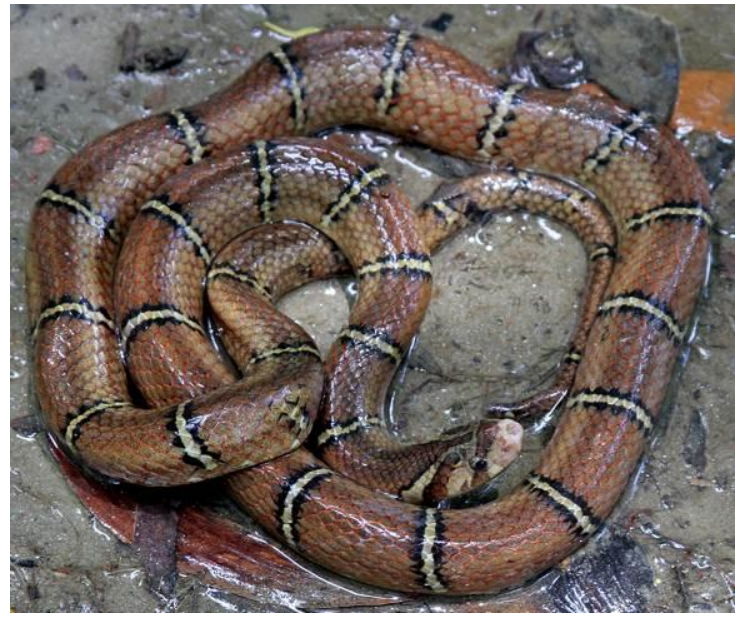

Figure 1: Live female Oligodon albocinctus (SVL $70 \mathrm{~cm})$, collected at Chunati Wildlife Sanctuary, Bangladesh (Cat. JUHG 00332)

The morphometric and meristic data confirm that the specimen was an adult female Oligodon albocinctus (Cantor, 1839) when compared with published literatures (Neang et al., 2012; David et al., 2008; Das, 2002; Smith, 1943; Whitaker \& Captain, 2004; Kabir et al., 2009). Body was comparatively robust with SVL $70.0 \mathrm{~cm}$; tail was incomplete. It differed from the superficially similar Oligodon kampucheaensis (Neang et al., 2012) by having DOR 19-19-17 instead of 15-15-15; VEN 194, SUB 50 and SUP-Eye 3+4 instead of 165, 39 and $4+5$ respectively; and BB 26 instead of 17 (Table 1).

The specimen was reddish-brown with 26 yellowish dorsal cross-bands on body and 7 cross-bands on its incomplete tail. Head elongated and slightly flattened; HL $18.0 \mathrm{~mm}$, HW $15.6 \mathrm{~mm}$ and HD $10.5 \mathrm{~mm}$. Snout elongated; SnL $6.6 \mathrm{~mm}$, EN $4.8 \mathrm{~mm}$, ND 6.2 $\mathrm{mm}$ and IO $9.2 \mathrm{~mm}$ (Fig. 2).

Table 1: Comparison of morphological and color pattern characters of Oligodon albocinctus with Oligodon kampucheaensis. Additional abbreviations: RCB, reticulated black colored crossbars; ab, absent; -, not mentioned.

\begin{tabular}{l|c|c|c}
\hline \multicolumn{1}{c|}{ Characters } & $\begin{array}{c}\text { O. albocinctus } \\
\text { (JUHG 00332) }\end{array}$ & $\begin{array}{c}\text { O. albocinctus } \\
\text { (Smith, 1943) }\end{array}$ & $\begin{array}{r}\text { O. kampucheaensis } \\
\text { (Neang et al., 2012) }\end{array}$ \\
\hline SVL & $70 \mathrm{~cm}$ & - & $36.32 \mathrm{~cm}$ \\
SUP & $7(3 / 4)$ & $7(3 / 4)$ & $8(4 / 5)$ \\
(touching eye) & 8 & - & 8 \\
INF & $1+2$ & 1 (anterior) & $1+2$ \\
TEMP & $19,19,17$ & - & $15,15,15$ \\
DOR & 194 & $177-208$ & 165 \\
VEN & $50+\mathrm{x}$ & $40-69$ & 39 \\
SUB & entire & - & entire \\
ANL & 12 & - & 11 \\
MAX & 26 & $19-27$ & 17 \\
BB & 7 & $4-8$ & 3 \\
BT & 8 & - & $8-9$ \\
SCB & ab & - & ab \\
RCB & & & \\
\hline
\end{tabular}

\section{Acknowledgements}

We are thankful to the Forest Department of Bangladesh for providing permission and support during the field work. The field work was conducted as a part of the biodiversity monitoring in Chunati Wildlife Sanctuary (LDFC) project funded by GIZ and Arannyak Foundation, Bangladesh and implemented by the wildlife research group of the Department of Zoology, Jahangirnagar University, we are thankful to them. We are also grateful to the authority of Wildlife Rescue Center (WRC) of Jahangirnagar University for their logistic support. Finally we would like to thank Gernot Vogel (Germany) for editing the manuscript. 

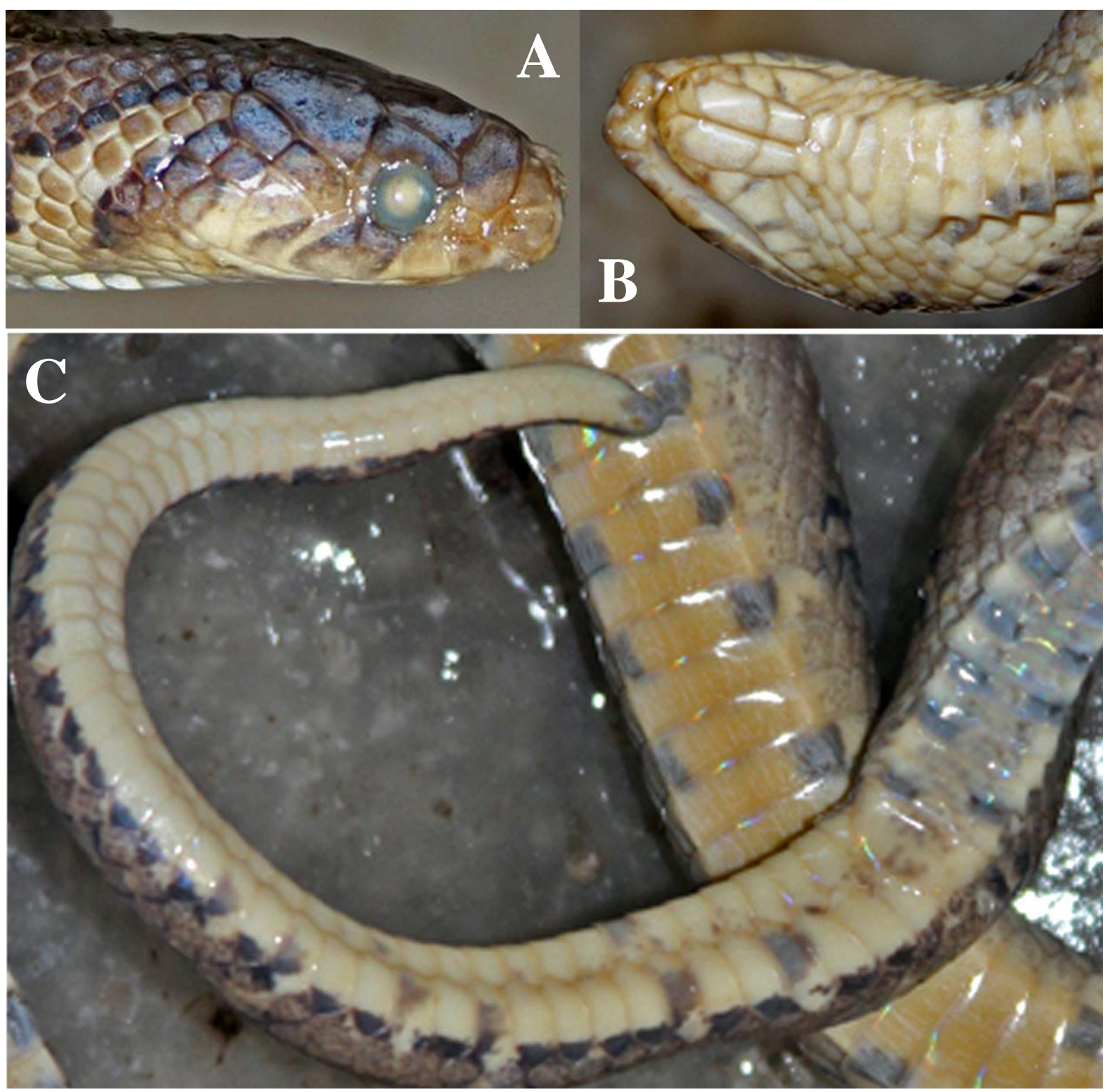

Figure 2: Oligodon albocinctus (JUHG 00332): A, lateral view of head; B, ventral view of head and C, subcaudal scales.

\section{Literature Cited}

Das, I., 2002. A photographic guide to snakes and other reptiles of India, New Holland Publishers, UK: 144.

Das, A., U. Saikia, B. H. C. K. Murthy, S. Dey and S. K. Dutta, 2009. A herpetofaunal inventory of Barail Wildlife Sanctuary and adjacent regions, Assam, north-east India. Hamadryad, 34 (1): 117-134.

David, P., G. Vogel and J. Van Rooijen, 2008. A revision of the Oligodon taeniatus (Günther, 1861) (Squamata: Colubridae) group, with the description of three new species from the Indochinese Region. Zootaxa, 1965: 1-49.
IUCN Bangladesh, 2003. Bangladesher Bipanno Banya Prani. IUCN, The World Conservation Union, Bangladesh: 294.

Kabir, S. M. H., M. Ahmed, A. T. A. Ahmed, Z. U. Ahmed, Z. N. T. Begum, M. A. Hassan and M. Khondker (eds.). 2009. Encyclopedia of Flora and Fauna of Bangladesh - volume 25. Asiatic Society of Bangladesh, Dhaka: 204.

Khan, M. A. R., 1982. Wildlife of Bangladesh: a checklist. Dhaka: University of Dhaka: 174.

Khan, M. A. R., 2010. Wildlife of Bangladesh, from amphibia to mammalia: a checklist. Shahitya Prakash, Dhaka: 128. 
Khan, M. M. H., 2008. Protected areas of Bangladesh: a guide to wildlife. Nishorgo Program, Bangladesh Forest Department, Dhaka, Bangladesh: 304.

Neang, T., L. L. Grismer and J. C. Daltry, 2012. A new species of kukri snake (Colubridae: Oligodon Fitzinger, 1826) from the Phnom Samkos Wildlife Sanctuary, Cardamom Mountains, southwest Cambodia. Zootaxa, 3388: 41-55.

Sarker, S. U. and N. J. Sarker, 1985. Reptiles of Bangladesh (with their status, distribution and habitat). Tigerpaper, 12: 6-12.

Sarker, S. U. and N. J. Sarker, 1988. Wildlife of Bangladesh: a systematic list with status, distribution and habitat. Rico Printers, Dhaka: 69

Smith, M. A., 1943. The fauna of British India, Ceylon and Burma, including the whole of the Indo-chinese subregion, reptilia and amphibianvolume III, Serpents. Taylor and Francis, London: 583.

Whitaker, R. and A. Captain, 2004. Snakes of India: the field guide. Draco Books, Chennai, India: 479.

Submitted: 11 Nov 2012, Accepted: 13 Jan 2013 Sectional Editor: Gernot Vogel

M. K. Hasan ${ }^{1,2}$, M. M. Feeroz ${ }^{1}$, S. Ahmed ${ }^{1}$ A. Ahmed ${ }^{1} \&$ S. Saha ${ }^{1}$

${ }^{1}$ Department of Zoology, Jahangirnagar University, Dhaka, Bangladesh

${ }^{2}$ Department of Anthropology, University of California Davis, USA E-mail: mkhasan@ucdavis.edu 